\title{
Characterization of Red Raspberry Cultivars and Selections Using Isoenzyme Analysis
}

\author{
J.C. Cousineau, A.K. Anderson, and H.A. Daubeny \\ Agriculture Canada, Research Station, 6660 N. W. Marine Drive, Vancouver, \\ B.C. V6T-1X2, Canada
}

\section{D.J. Donnelly}

Department of Plant Science, Faculty of Agricultural and Environmental Sciences, McGill University, Macdonald Campus, 21,111 Lakeshore Road, Ste-Anne-de-Bellevue, Que. H9X 3V9, Canada

Additional index words. Rubus idaeus, starch gel electrophoresis

\begin{abstract}
Isoenzyme staining of horizontal starch gels was used to characterize 23 cultivars and three advanced selections of red raspberry (Rubus idaeus L.). The genotypes were separable using the enzymes malate dehydrogenase, phosphoglucoisomerase, phosphoglucomutase, and triose phosphate isomerase. In addition, staining for isocitrate dehydrogenase and shikimate dehydrogenase revealed polymorphisms in some cultivars. By combining these results with those obtained for 78 previously tested cultivars, 75 of the 104 (72\%) genotypes tested were uniquely characterized using the six isoenzymes.
\end{abstract}

patterns do not result from the presence of new alleles but rather are variations in the combinations of previously described alleles (Cousineau and Donnelly, 1992b).

The results obtained for the 26 genotypes above and the 78 cultivars previously analyzed (Cousineau and Donnelly, 1992a) were combined. In all, 75 of the $104(72 \%)$ genotypes tested were uniquely characterized using the six isoenzymes. Of the new genotypes tested, the following were not resolved: 'Amity' from 'Milton' and 'Washington', BC83-16-50from 'Redwing' and 'Tulameen', 'Vene' from 'Nootka', and 'Wawi' from 'Sumner'.

After converting isoenzyme patterns to allelic designations, the patterns of BC83-16-50 ('Glen Moy' x 'Chilliwack'), 'Himbo Queen' ('puyallup' $\times$ 'Mailing Exploit'), 'Redbrook' ('Boyne' $x$ 'Chief'), and 'Wawi' ('Washington' $x$ ' Willamette' ) were consistent with their pedigrees.

Isoenzyme staining of starch gels is a technique that is accessible to laboratories with modest facilities due to its simplicity and relatively low cost. It has proven useful for characterizing raspberry genotypes and can therefore be used by propagators and breeders to
Starch gel electrophoresis and isoenzyme staining resulted in the unique characterization of 55 of 78 red raspberry (Rubus idaeus L.) cultivars assayed (Cousineau and Donnelly, 1992a). The objective of the present study was to determine the isoenzyme patterns of an additional 23 cultivars not previously tested and three advanced selections from the Agriculture Canada breeding program at the Vancouver Research Station. It is important that patterns of as many cultivars and selections as possible be available to aid in correct identification for propagation and breeding.

The cultivars and selections (Table 1) were maintained as pot plants or in the field. The following enzymes were analyzed: isocitrate dehydrogenase (IDH, EC 1.1.1.42), malate dehydrogenase (MDH, EC 1.1. 1.37), phosphoglucoisomerase (PGI, EC 5.3.1.9), phosphoglucomutase (PGM, EC 2.7.5.1), shikimate dehydrogenase (SKDH, EC 1.1. 1.25), and triose phosphate isomerase (TPI, EC 5.3.1.1). Enzyme extraction from leaves, horizontal starch gel electrophoretic procedures, and isoenzyme staining techniques were as described by Cousineau and Donnelly (1992a).

The 26 genotypes analyzed were uniquely characterized using MDH, PGM, PGI, and TPI (Table 1). The remaining two enzymes, IDH and SKDH, were not needed for characterization, although polymorphisms were detected in some cultivars. Two new patterns were obtained for PGM: K for 'Bababerry' and L for 'Mailing Augusta' (Fig. 1). These

Received for publication 8 Mar. 1993. Accepted for publication 29 June 1993. We are grateful to A. Dale for providing a compilation of raspberry pedigrees. The cost of publishing this paper was defrayed in part by the payment of page charges. Under postal regulations, this paper therefore must be hereby marked advertisement solely to indicate this fact.
Table 1. Identification of red raspberry cultivars and selections using six isoenzymes. The letters represent the cultivar banding patterns for each enzyme as described in Cousineau and Donnelly (1992a) and in Fig. 1.

\begin{tabular}{|c|c|c|c|c|c|c|c|}
\hline \multirow{2}{*}{$\begin{array}{l}\text { Cultivar or } \\
\text { selection }\end{array}$} & \multirow[b]{2}{*}{ Source $^{2}$} & \multicolumn{6}{|c|}{ Isoenzyme and pattern } \\
\hline & & $\mathrm{MDH}$ & PGM & PGI & TPI & IDH & SKDH \\
\hline Ljulin & 1 & A & c & A & B & c & A \\
\hline Ruby & 2 & A & c & c & c & A & A \\
\hline Balder & 3 & A & G & B & A & c & A \\
\hline Bababerry & 4 & A & $\mathrm{K}$ & $\mathrm{B}$ & c & A & $\mathrm{A}$ \\
\hline BC $85-5-24^{y}$ & 5 & B & c & A & B & A & A \\
\hline Rumiloba & 6 & B & c & A & $\mathrm{E}$ & A & A \\
\hline Мeco & 7 & B & c & B & B & A & c \\
\hline Rucanta & 6 & B & c & B & $\mathrm{E}$ & A & A \\
\hline Vene & 8 & B & c & $\mathrm{E}$ & A & A & A \\
\hline Wawi & 7 & c & D & A & A & A & A \\
\hline Amity & 9 & c & $\mathrm{D}$ & B & A & A & A \\
\hline Cherokee & 10 & $\mathrm{c}$ & $\mathrm{D}$ & c & A & A & B \\
\hline Dinkum & 11 & D & A & $\mathrm{c}$ & A & A & A \\
\hline Fallbrook & 12 & $\mathrm{D}$ & B & $\mathrm{c}$ & A & A & A \\
\hline ВC83-16-50Y & 5 & $\mathrm{D}$ & $\mathrm{c}$ & A & A & A & A \\
\hline Fertodi Zamatos & 13 & $\mathrm{D}$ & $\mathrm{c}$ & A & B & A & A \\
\hline BC85-18-16Y & 5 & D & $\mathrm{c}$ & A & c & A & A \\
\hline Autumn Cascade & 14 & $\mathrm{D}$ & $\mathrm{c}$ & A & $\mathrm{E}$ & A & A \\
\hline Himbo Queen & 15 & $\mathrm{D}$ & $\mathrm{D}$ & A & A & A & A \\
\hline Polana & 1 & $\mathrm{D}$ & $\mathrm{D}$ & $\mathrm{D}$ & A & $\mathrm{c}$ & $\mathrm{A}$ \\
\hline Glen Clova & 16 & D & G & A & $\mathrm{c}$ & A & A \\
\hline Beskid & 1 & $\mathrm{D}$ & $\mathrm{G}$ & $\mathrm{E}$ & B & A & A \\
\hline Mailing Augusta & 14 & $\mathrm{D}$ & $\mathrm{L}$ & c & A & A & $\mathrm{c}$ \\
\hline Redbrook & 12 & $\mathrm{~F}$ & B & A & A & $\mathrm{c}$ & A \\
\hline Perron's Red & 17 & K & $\mathrm{D}$ & A & $\mathrm{c}$ & $\mathrm{A}$ & A \\
\hline Trailblazer & 18 & $\mathrm{~N}$ & $\mathrm{H}$ & A & A & A & A \\
\hline
\end{tabular}

${ }^{2} 1$ = J. Danek, Research Inst. of Pomology and Floriculture, Fruit Experimental Station, Podegrodzie, Poland; $2=\mathrm{K}$. Maloney, Dept. of Horticultural Sciences, New York State Agricultural Experiment Station, Cornell Univ., Geneva; 3 = G. Redelen, Agricultural Univ. of Norway, Dept. of Horticulture; $4=$ North Star Gardens, St. Paul, Minn. $5=$ H.A. Daubeny, Agriculture Canada, Research Station, Vancouver, B.C.; 6 = A. Bauer, Hechlstraase 11, Breitbrunn, Germany; 7 = J.M. Boré, Institut National de Recherches Agronomiques, Station d'Amélioration des Espèces Fruitières et Ornementales, Angers, France; $8=$ R. Nestby, Kvithamar Research Station, Stjordal, Norway; $9=$ Sakuma Bros. Farms, Burlington, Wash.; $10=$ P. Moore, Western Washington Research \& Extension Center, Puyallup; $11=$ = G. McGregor, Institute of Plant Sciences, Dept. of Agriculture, Toolangi, Victoria, Australia; $12=$ Alberta Horticultural Research Center, Brooks, Canada; $13=\mathbf{L}$. Kollányi, Gyümöles-És Disznövénytermesztési, Kutató - Fejlesztö Vállalat Allomása, Fertöd, Hungary; 14 = V. Knight, Horticulture Research International, East Malling, Maidstone, Kent, England; $15=$ H. Wicki, Hauenstein AG, Switzerland; $16=$ D. Jennings, Scottish Crop Research Institute, Invergowrie, Dundee; 17 = T. Huber, W.H. Perron \& Co., Montreal, Que., Canada; 18 = F.J. Lawrence, National Clonal Germplasm Repository, Corvallis, Ore.

'BC85-5-24 ('Meeker'x BC78-53-116); BC83-16-50 ('Glen Moy' x 'Chilliwack'); BC85-18-16 ('Comox' x East Malling 3909/4). 


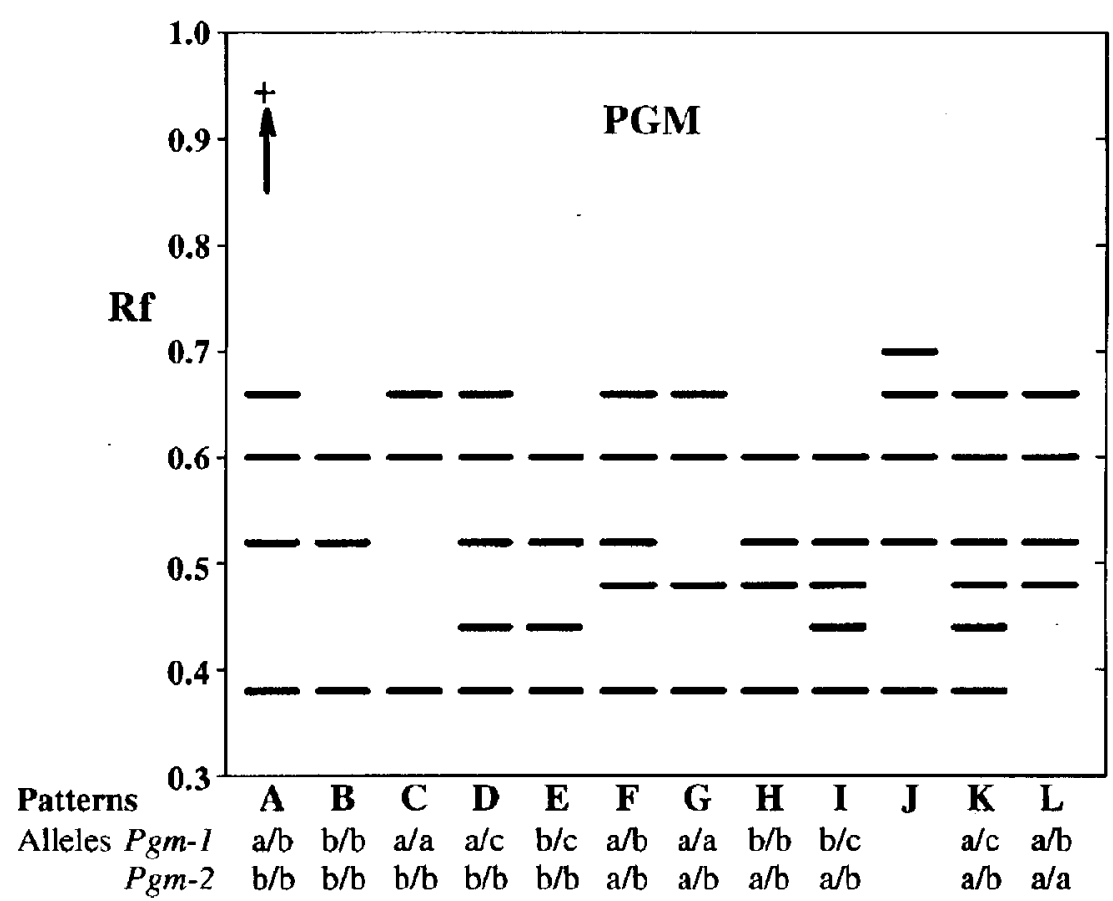

Fig. 1. Interpretative drawing of two phosphoglucomutase (PGM) isoenzyme patterns and allelic designations based on Cousineau and Donnelly ( 1992b). Patterns A-H were previously described in Cousineau and Donnelly (1992a). Allelic designation of pattern J was not possible, since the band at Rf 0.7 could not be assigned with certainty to either of the PGM loci. confirm raspberry identity. Morphological differences, such as spine color and density or the presence of waxy bloom, maybe helpful in distinguishing those cultivars that are inseparable in the vegetative stage using isoenzyme staining. In laboratories with adequate facilities, techniques such as hypervariable minisatellite DNA analysis (Nybom et al., 1989; Parent and Pagé, 1992) or chloroplast DNA analysis (Moore, 1993) may also be used to resolve cultivars that are similar iso-enzymically.

\section{Literature Cited}

Cousineau, J.C. and D.J. Donnelly. 1992a. Use of isoenzyme analysis to characterize raspberry cultivars and detect cultivar mislabeling. HortScience 27:1023-1025.

Cousineau, J.C. and D.J. Donnelly. 1992b. Genetic analysis of isoenzymes in raspberry. J. Amer. Soc. Hort. Sci. 117:996-999.

Moore, P.P. 1993. Chloroplast DNA diversity in raspberry. J. Amer. Soc. Hort. Sci. 118:371376.

Nybom, H; B.A. Schaal, and S.H. Rogstad. 1989. DNA "fingerprints" can distinguish cultivars of blackberries and raspberries. Acts Hort. 262:305-310

Parent, J.-G. and D. Pagé. 1992. Identification of raspberry cultivars by nonradioactive DNA fingerprinting. HortScience 27: 1108-1 110 . 